\title{
Comparing the Diet of Great Horned Owls (Bubo virginianus) in Rural and Urban Areas of Southwestern British Columbia
}

\author{
SOFI HINDMARCH ${ }^{1,3}$ and JOHN E. ElLIOTT ${ }^{2}$ \\ ${ }^{1}$ Langley, British Columbia, Canada \\ ${ }^{2}$ Environment Canada, Science and Technology Branch, Delta, British Columbia V4K 3N2 Canada \\ ${ }^{3}$ Corresponding author: sofi.hindmarch@gmail.com
}

Hindmarch, Sofi, and John E. Elliott. 2014. Comparing the diet of Great Horned Owls (Bubo virginianus) in rural and urban areas of southwestern British Columbia. Canadian Field-Naturalist 128(4): 393-399.

We investigated the diet of Great Horned Owls (Bubo virginianus) in southwestern British Columbia. Our objective was to compare the diets of owls in urban and rural areas and determine whether urban owls consume a higher proportion of commensal rodents to understand possible pathways of secondary rodenticide poisoning of Great Horned Owls. Among 546 prey items identified at seven sites, Townsend's Vole (Microtus townsendii [Bachman, 1839]) and rats (Rattus G. Fischer, 1803) were the two main prey items, making up $65.9 \%$ and $13.1 \%$ of the diet, respectively. The proportion of rats in the diet was positively correlated with the degree of urban development in the owls' home range $\left(r_{p}=0.83, P<0.05, \mathrm{df}=5\right)$.

Key Words: Great Horned Owl; Bubo virginianus; diet; British Columbia; voles; Townsend's Vole; Microtus townsendii; rats; Rattus; rodenticide

\section{Introduction}

The Great Horned Owl (Bubo virginianus) is found throughout North America, except in the Arctic, making it the most common and widespread owl on the continent (Houston et al. 1998*). The large and diverse range of the Great Horned Owl is also reflected in its diet. As a generalist and opportunistic feeder, it consumes a wide range of prey species, including lagomorphs, rodents, waterfowl, game birds, raptors, insects, and even larger birds, such as herons (Houston et al. 1998*; Johnsgard 2002). Although a diverse array of prey species have been identified, over most of the Great Horned Owl's range, its diet consists of $90 \%$ mammals, predominantly rodents, and $10 \%$ birds (Houston et al. 1998*; Johnsgard 2002).

Despite several studies and reviews investigating the food habits of the Great Horned Owl in a variety of regions of North America (Houston et al. 1998*; Johnsgard 2001), no Great Horned Owl diet studies have been conducted in southwestern British Columbia, and only one such study has been reported from the province (Van Damme 2005). Most previous studies have been conducted in forest, grassland, and agricultural settings; few have investigated the diet of the Great Horned Owl in more urban landscapes. Like other predatory birds, such as the Sharp-shinned Hawk (Accipiter striatus) and the Northern Goshawk (Accipiter gentilis), Great Horned Owls are increasingly finding niches in urban ecosystems across North America (Lambert 1981; Powers 1996; Rutz 2008) where their exposure to environmental contaminants may be enhanced, especially through consuming rodents that have previously ingested anticoagulant rodenticides. The risk of secondary exposure to these rodenticides in raptors is currently receiving increased attention in Canada (Albert et al. 2010; Thomas et al. 2011; Elliott et al. 2014).

Our study had two objectives: to obtain dietary information for Great Horned Owls in a region where no previous data had been collected and to compare the diet of owls that inhabit agricultural versus suburban landscapes in southwestern British Columbia. Such data are of particular interest in rapidly urbanizing regions, such as southwestern British Columbia, where the loss of forests and agricultural lands surrounding urban centres forces owls and other wildlife into the remaining patches of green space, such as parks, suburban woodlots, and fragments of undeveloped land. We were specifically interested in evaluating whether the amount of urban development within Great Horned Owl home ranges influenced the consumption of commensal rodents such as Norway Rats (Rattus norwegicus [Berkenhout 1769]), Black Rats (Rattus rattus [L., 1758]), and House Mice (Mus musculus L., 1758), which are the species commonly targeted for control with anticoagulant rodenticides.

\section{Study Area}

Surveys for Great Horned Owl nest and roost sites were conducted from December 2010 to December 2013 in the municipalities of Richmond, Vancouver, Burnaby, Delta, Surrey, and New Westminster (a total area of $\left.847 \mathrm{~km}^{2}\right)$ in southwestern British Columbia, Canada $\left(49^{\circ} 8^{\prime} \mathrm{N}, 122^{\circ} 18^{\prime} \mathrm{W}\right)$. The area includes some of the main stopover sites for birds migrating on the Pacific flyway and encompasses important wildlife areas such as the Alaksen National Wildlife Area, Burns Bog, Stanley Park, Pacific Spirit Regional Park and Boundary Bay Regional Park. Before European settlement, the low-lying floodplains were dominated by grassland, low shrub vegetation, and extensive stands of 
mixed woodlands dominated by cottonwood, alder, and cedar, while higher elevations were covered primarily by mixed coniferous forest (North and Teversham 1984). Today, the landscape ranges from agricultural to suburban to highly urban, and the remaining lower grassland and forested habitats face ongoing development pressure as the projected human population in the region is expected to increase from the current 2.4 million to 3.4 million in 2040 (Metro Vancouver 2009*).

\section{Methods}

Owl surveys, pellet collection and analyses

Suitable areas to survey for nest and roost sites and, thus, pellet and prey remains were identified with the collaboration of local natural history clubs and by surveying parks and green spaces for signs of owl presence, such as whitewash, feathers, and pellets. To confirm the presence of Great Horned Owls and to guide pellet searching in larger parks, call play-back was used at dusk following the North American nocturnal owl survey guidelines (Takats et al. 2001*). When we found evidence of an owl roosting or nesting, we revisited the site every 2-3 months to search for additional pellets and prey remains. Although the potential for occasional loss of larger prey remains to scavenging existed (Marti et al. 2007), we believe there would likely be sufficient remains of such large prey items to allow identification. Incidental observations of foraging and prey type were also recorded.

\section{Pellet analysis}

We dissected pellets carefully to ensure that prey items could be identified from bone remnants, fur and other body parts using British Columbia small mammal field guides (Nagorsen 1996, 2005). We determined the number of individuals of any species in each pellet by pairing each skull with the correct number of ischia, left and right mandibles, and tibiae/fibulae or, in the case of birds, each skull with sternum, gizzard sac, and feet. We assembled the remaining bones in the pellet to determine the minimum number of additional individuals whose skull may have been crushed. For smaller prey items $(<100 \mathrm{~g})$, we assumed that the remains of each were contained in a single pellet, as finding bones from one prey item in two successive pellets is rare (Raczynski and Ruprecht 1974). We estimated the weights of rats from intact jaw bones in the prey remains following Morris (1973).

Very few rat (Norway Rat or Black Rat) and shrew (Vagrant Shrew (Sorex vagrans) and Montane shrew (Sorex monticolus) prey remains were sufficiently intact to determine species) and, hence, we pooled all rats and shrews into one category. For the same reason, we allocated songbird (Passeriformes) prey remains to two categories: small songbirds $(<30 \mathrm{~g})$ and medium songbirds (30-80 g). We considered all insect exoskeleton remains to belong to the order Coleoptera.

\section{Evaluation of land use within home ranges}

In examining differences in the diet of Great Horned Owls between agricultural and suburban sites, we quantified the amount of urban land (residential, industrial, and transportation) within a $1-\mathrm{km}$ radius $\left(3 \mathrm{~km}^{2}\right.$ or $300 \mathrm{ha}$ ) of each nest or roost site from digitized data layers using geographic information system software (ArcMap 10, Esri, Redlands, California, USA). We used a $1-\mathrm{km}$ radius, as the average home range of the Great Horned Owl is approximately $3 \mathrm{~km}^{2}$ (Petersen 1979*; Houston et al. 1998*). Data on land use within the home ranges were obtained from a 2006 Vancouver Regional District land-use layer map that categorized land parcels based on zoning (Metro Vancouver 2008*). We compared the 2006 land-use layer map with 2010 Bing Ortho photos (Bing Maps, Microsoft, Redmond, Washington, USA) to control for any recent changes in land use or discrepancies between current land use and zoning.

We conducted a Pearson correlation analysis to determine if there was any relationship between the amount of urban development within home ranges and the proportion of rats in the diet of Great Horned Owls. The Pearson correlation analysis was carried out using IBM SPSS 22 (IBM Inc. Armonk, New York, USA).

\section{Results}

We found seven sites (five nests and two roosts) occupied by Great Horned Owls in our study area and monitored them regularly. Three sites were located in predominantly agricultural landscapes (Alaksen National Wildlife Area, Forest Richmond, and Arthur Drive) and four in urban parks and green spaces (Terra Nova Park, Beach Grove Park, Crescent Park, and Central Surrey). The proportion of urban development within Great Horned Owl home ranges $\left(3 \mathrm{~km}^{2}\right)$ varied considerably, from $0 \%-7.6 \%$ at rural sites to $33.8-93.3 \%$ at urban ones (Table 1).

Pellets and prey remains were found predominantly under nest or roost trees. Some pellets were weathered considerably, and it was impossible to get an exact count of the number of pellets collected, but, in total, 546 prey items of 21 species were identified. Overall, Townsend's Vole (Microtus townsendii [Bachman, 1839]) was the most common $(65.9 \%)$, and was the dominant prey species at six of the seven sites, followed by Rattus spp. (13.1\%). Other species were only marginally represented in the diet, each contributing less than $5 \%$ of the total number of individuals overall (Table 1). On average 7.1 prey species were identified at each site (range 2-9), and the intact prey ranged in weight from about $1 \mathrm{~g}$ (e.g., beetle) to over $2 \mathrm{~kg}$ (Great Blue Heron, Ardea herodias).

In the late summer and fall of 2012, one Great Horned Owl pair residing in Terra Nova Park, Richmond, was observed by park employees preying on Barn Owls (Tyto alba) (Figure 1). In total, eight Barn 


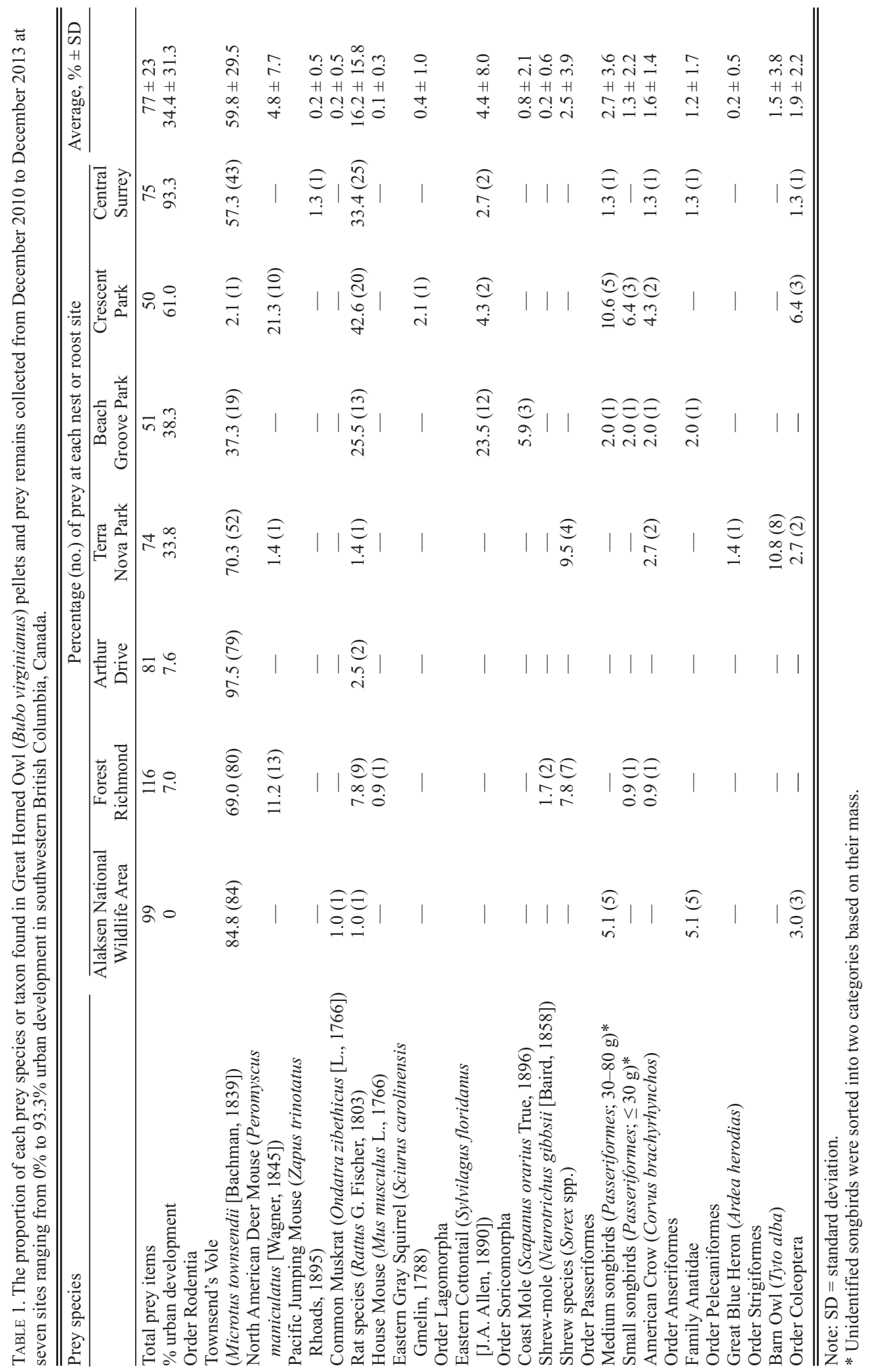




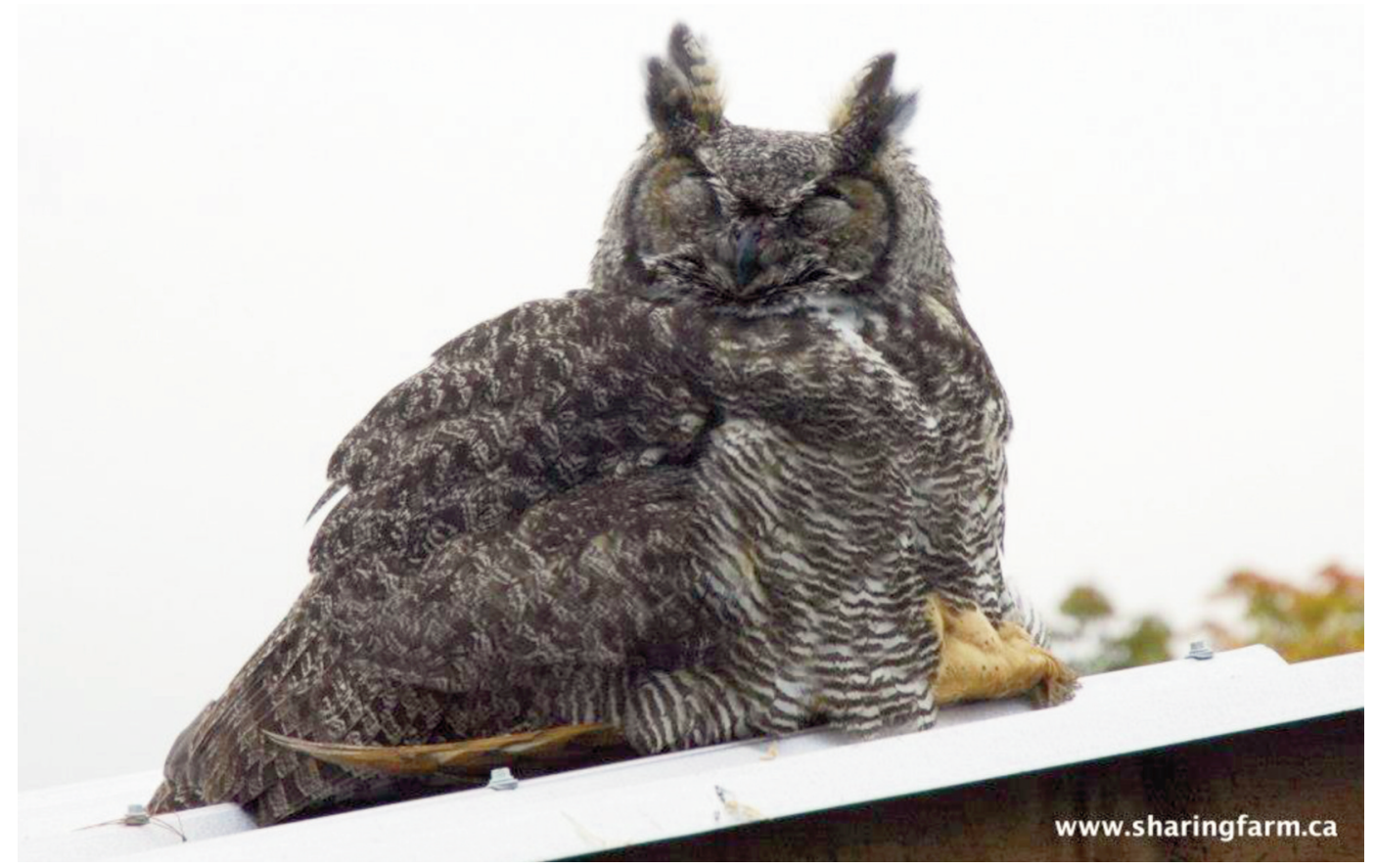

FIGURE 1. Great Horned Owl (Bubo virginianus) sitting on shed roof with a captured Barn Owl (Tyto alba). The Great Horned Owl pair at Terra Nova Park, Richmond, caught a total of eight Barn Owls in fall 2012. Photographed 10 October 2012 at Terra Nova Park Richmond; photo by Sharing Farm.

Owls were preyed on, most probably young of the year as band recovery confirmed that two were recently fledged chicks from nest sites 14 and $34 \mathrm{~km}$ away. Eastern Cottontails (Sylvilagus floridanus [J. A. Allen, 1890]) were not an important component of the diet and were recorded at only three urban sites. However, at one nest site located in a park, they were the second most consumed prey along with rats at $23.5 \%$. Further, only one House Mouse (Mus musculus L., 1766) and one Eastern Gray Squirrel (Sciurus carolinensis Gmelin, 1788) were found among all prey remains.

Following Morris' (1973) model for predicting the body weight of rat prey items, the average mass of rats consumed by Great Horned Owls was $118 \pm 63.3 \mathrm{~g}$ (range 20-280 g, $n=39$ ). Based on the mode (Figure 2), Great Horned Owls most frequently consumed rats

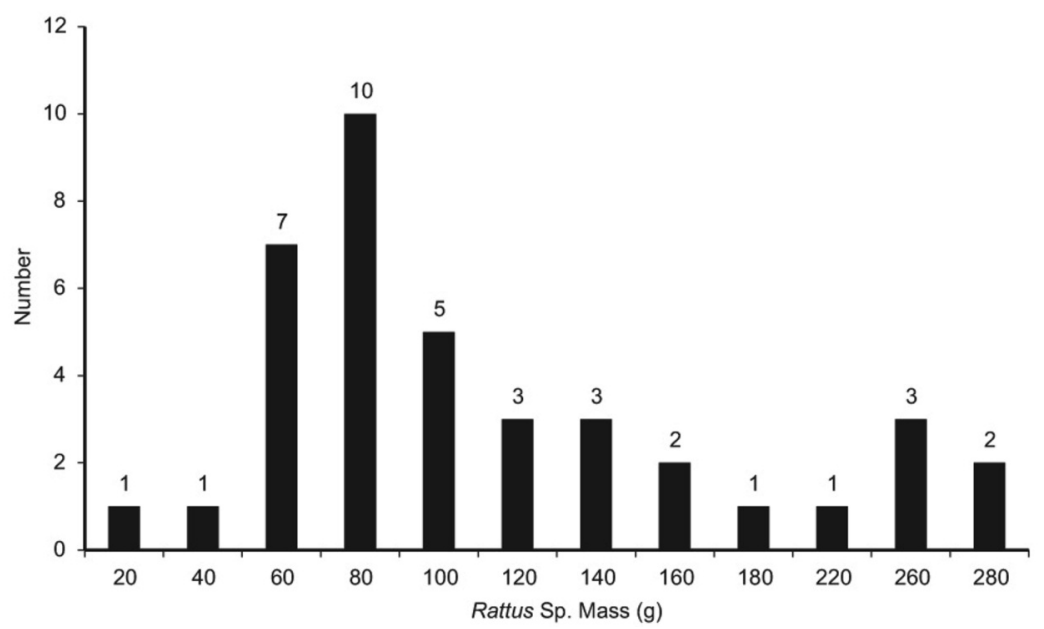

FiguRE 2. Number of rats (Rattus spp.) by weight class consumed by Great Horned Owls (Bubo virginianus) at seven sites in southwestern British Columbia, Canada (average $=118 \pm 63.3 \mathrm{~g}$ ). 
weighing $80 \mathrm{~g}$. The difference between the average and the mode is explained by the Great Horned Owls' capability of capturing rats of all sizes, including the occasional larger rat $(>200 \mathrm{~g})$. The proportion of rats in the diet was significantly correlated with the amount of urban land within home ranges $\left(r_{p}=0.83, P<0.05\right.$, $\mathrm{df}=5$ ).

\section{Discussion}

Despite the highly flexible foraging behaviour of Great Horned Owls, they tend to focus on only one or two profitable prey species within a geographic region (Houston et al. 1998*; Marchesi et al. 2002). The food habits of the Great Horned Owls within our study area showed no exception to this trend. Overall, Townsend's Voles dominated the diet followed by rats, and a diverse range of other species each accounted for less than 5\% of the prey consumed at all sites combined. Land use surrounding individual nest and roost sites likely influenced the diversity and abundance of available prey species and, ultimately, the diet of Great Horned Owl pairs. This was evident from the consumption of rats, which increased as home ranges became gradually more urban.

The move toward increased rat consumption in more urban environments was previously documented in Great Horned Owls nesting in city parks in Seattle, Washington (Lambert 1981). Similarly, the larger cousin of the Great Horned Owl, the Eurasian Eagle Owl (Bubo bubo) consumed more rats when nesting in European urbanized landscapes (Marchesi et al. 2002; Sandor and Ionesco 2009), while the diet of a pair of Desert Eagle Owls (Bubo ascalaphus) in the city of Hurghada, Egypt, was made up of $71.8 \%$ House Mice and Norway Rats (Sandor and Moldovan 2010). In South Korea, Eurasian Eagle Owls consumed rats predominantly in both urban and agricultural landscapes (Shin et al. 2013). In all cases, the increased consumption of rats was attributed to their status as an abundant, stable, year-round food source. In our study, Great Horned Owls consumed predominantly smaller rats, which are likely to be more abundant, less risky to handle, and faster to process than larger rats.

Among other commensal rodents, only one House Mouse was found. Similarly, only one Eastern Gray Squirrel was recorded, at a nest in an urban park, despite the abundance of squirrels in all urban and rural parks, at least partly a result of public feeding (S. Hindmarch personal observation).

Second-generation anticoagulant rodenticides (SGARs) used to suppress commensal rodent populations worldwide, have been shown to be persistent, highly bioaccumulative, and very toxic to non-target species (Parmar et al. 1987; US EPA 2004*). Among raptors, Great Horned Owls have one of the highest rates of exposure to, and toxicity from these rodenticides (Stone et al. 1999; 2003; Albert et al. 2010; Murray 2011, Thomas et al. 2011). Further, predators may be at a greater risk of SGAR exposure in urban settings where larger quantities of these compounds are used to suppress commensal rodent populations (Stone et al. 1999, 2003; Riley et al. 2007; McMillin et al. 2008).

In southwestern British Columbia, $70 \%(n=61)$ of Great Horned Owl carcasses tested between 1988 and 2003 contained one or more SGARs (Albert et al. 2010). More recently, all of the Great Horned Owls collected in southwestern British Columbia between 2005 and $2011(n=29)$ tested positive for one or more SGARs (J.E.E. unpublished data). There is some evidence to suggest that non-target species including native mice and voles, squirrels, and passerines enter SGAR bait stations and feed (US EPA 2004*; Brakes and Smith 2005; Tosh et al. 2012), although rats are likely one of the main vectors responsible for secondary exposure of non-target predators (Cox and Smith 1990; Birks 1998; Elliott et al. 2014). Our data showing increased consumption of rats by urban Great Horned Owls are consistent with the idea that rats are the main source of exposure to SGARs. However, the dominance of Townsend's Voles in the diet of Great Horned Owls suggests the need for SGAR residue sampling in nontarget small mammals in addition to rats in urban environments.

Our land-use analysis may not have been able to identify fine-scale landscape differences between sites. For example, one Great Horned Owl pair nesting in an urban nature park (26 ha) consumed predominantly Townsend's Voles (70.3\%), and only 2 rats were found in the pellets. Although that park is surrounded by residential development, over recent years an old field restoration project has resulted in the removal of invasive plant species and an increase in the abundance of Townsend's Voles, with the expressed goal of encouraging the nesting of raptors. This was also the site where the Great Horned Owl pair consumed eight Barn Owls and one Great Blue Heron in the fall of 2012. Great Horned Owl predation on Barn Owls has been documented previously (Rudolph 1978, Knight and Jackman 1984, Millsap and Millsap 1987, and Van Damme 2005). In this case, on several occasions we observed a Great Horned Owl entering a Barn Owl nest box to feed. Such behaviour can be prevented by reducing the size of the entry hole on Barn Owl nest boxes and installing a vertical predator guard on the inside. The size of the entry hole was reduced on all the boxes in the park shortly after these observations were made.

Our diet data revealed that Great Horned Owls in southwestern British Columbia feed primarily on voles and rats. Despite our small sample size, the consumption of rats was significantly higher among Great Horned Owls with a higher proportion of urban land within their home range. The increased consumption of rats and the negligible number of House Mice and squirrels in the diet indicate that rats could be a major 
pathway for secondary SGAR exposure in Great Horned Owls.

\section{Acknowledgements}

We thank Paul Levesque and Alexa and Jamie Coote for their great help in looking for owl pellets. In many instances, their efforts included crawling around in the rough understory of urban parks. We appreciate and thank Sean McCann's efforts in proofreading and providing constructive comments on an earlier draft of this manuscript. Also, we wish to thank the two independent reviewers for their knowledgeable insights and efforts in reviewing our manuscript. Funding for this research was provided to John Elliott by the Pesticide Science Fund of Environment Canada.

Documents Cited (marked * in text)

Metro Vancouver. 2008. Metro Vancouver land use data. Metro Vancouver, Vancouver, British Columbia, Canada. Accessed 31 March 2008. www.metrovancouver.org/

Metro Vancouver. 2009. Metro 2040 residential growth projections. Metro Vancouver, Vancouver, British Columbia, Canada. Accessed 5 April 2013. www.metrovancouver .org/planning/development/strategy/RGSBackgrounders New/RGSMetro2040ResidentialGrowth.pdf

Takats, L. D., C. M. Francis, G. L. Holroyd, J. R. Duncan, K. M. Mazur, R. J. Cannings, W. Harris, and D. Holt. 2001. Guidelines for nocturnal owl monitoring in North America. Beaverhill Bird Observatory and Bird Studies Canada, Edmonton, Alberta. 32 pages. Accessed 10 October 2011. www.bsc-eoc.org/download/Owl.pdf

Erickson, W., and Ruban, D. 2004. Attachment D: Incident data for birds and nontarget mammals. Pages 183-213 in Potential Risks of Nine Rodenticides to Birds and Nontarget Mammals: a Comparative Approach. United States Environmental Protection Agency, Washington, DC, USA. Accessed 5 November 2011. http://pesticideresearch.com /site/docs/bulletins/EPAComparisonRodenticideRisks.pdf

\section{Literature Cited}

Albert, C. A., L. K. Wilson, P. Mineau, S. Trudeau, and J. E. Elliott. 2010. Anticoagulant rodenticides in three owl species from Western Canada, 1988-2003. Archives of Environmental Contamination and Toxicology 58: 451459 .

Birks, J. D. S. 1998. Secondary rodenticide poisoning risk arising from winter farmyard use by the European polecat Mustela putorius. Biological Conservation 85: 233-240.

Brakes, C. R., and R. H. Smith 2005. Exposure of non-target small mammals to rodenticides: short-term effects, recovery and implications for secondary poisoning. Journal of Applied Ecology 42: 118-128.

Cox, P.R. and R.H. Smith. 1990. Rodenticide ecotoxicology: assessing non-target population effects. Functional Ecology 4: 315-320.

Elliott, J. E., S. Hindmarch, C. A. Albert, J. Emery, P. Mineau, and F. Maisonneuve. 2014. Exposure pathways of anticoagulant rodenticides to nontarget wildlife. Environmental Monitoring and Assessment 186: 895-906.

Houston, C. S., D. G. Smith, and C. Rohner. 1998. The Great Horned Owl (Bubo virginianus) in The Birds of North America Online. Edited by A. Poole. Cornell Lab of Ornithology,
Ithaca, New York, USA. Accessed 15 November 2013. http://bna.birds.cornell.edu.proxy.lib.sfu.ca/bna/species/ 372doi:10.2173/bna.372.

Johnsgard, P. A. 2002. North American Owls: Biology and Natural History, Second edition. Smithsonian Institution Press, Washington, DC, USA. 298 pages.

Knight, R. L., and R. E. Jackman. 1984. Food-niche relationships between Great Horned Owls and Common Barn-Owls in Eastern Washington. The Auk 101: 175-179.

Lambert, A. 1981. Presence and food preferences of the Great Horned Owl in the urban parks of Seattle. The Murrelet 62: $2-5$.

Marchesi, L., F. Sergio, and P. Pedrini. 2002. Cost and benefits of breeding in human-altered landscapes for the Eagle Owl Bubo bubo. Ibis 144: 164-177.

Marti, M., M. Behcard, and F. M. Jaksic. 2007. Food habits. Pages 129-152 in Raptor Research Management Techniques. Edited by D. M. Bird and K. L. Bildstein. Hancock House Publishers Ltd, Surrey, British Columbia, Canada.

McMillin, S. C., R. C. Hosea, B. F. Finlayson, B. L. Cypher, and A. Mekebri. 2008. Anticoagulant rodenticide exposure in an urban population of the San Joaquin Kit Fox. Pages 163-1655 in Proceedings of the 23rd Vertebrate Pest Conference. Edited by R. M. Timm and M. B. Madon. University of California, California, USA.

Millsap, B. A., and P. A. Millsap. 1987. Burrow nesting by Common Barn-Owls in north central Colorado. Condor 89: 668-670.

Morris, P. 1973. Rats in the diet of the Barn Owl (Tyto alba). Notes from the Mammal Society 39: 540-545.

Murray, M. 2011. Anticoagulant rodenticide exposure and toxicosis in four species of birds of prey presented to a wildlife clinic in Massachusetts, 2006-2010. Journal of Zoo and Wildlife Medicine 42: 88-97.

Nagorsen, D. W. 1996. Opossums, Shrews and Moles of British Columbia. University of British Columbia Press, Vancouver, British Columbia, Canada. 164 pages.

Nagorsen, D. W. 2005. Rodents and Lagomorphs of British Columbia. University of Washington Press, Seattle, Washington, USA. 400 pages.

North, M. E. A., and J. M. Teversham. 1984. The vegetation of the flood plains of the Lower Fraser, Serpentine and Nicomekl rivers, 1859 to 1890 . Syesis 17: 47-66.

Parmar, G., H. Bratt, R. Moore, and P. L. Batten. 1987. Evidence for a common binding-site in vivo for the retention of anticoagulants in rat liver. Human Toxicology 6: 431-432.

Petersen, L. 1979. Ecology of Great Horned Owls and RedTailed Hawks in southern Wisconsin. Wisconsin Department Natural Resources Technical Bulletin 111: 1-63.

Powers, L. R. 1996. Wintering Sharp-Shinned Hawks (Accipiter striatus) in an urban area of southwestern Idaho. Northwestern Naturalist, 77: 9-13.

Raczynski, J., and A. L. Ruprecht. 1974. The effect of digestion on osteological composition of owl pellets. Acta Ornithologia 14: 25-38.

Riley, S. P. D., C. Bromley, R. H. Poppenga, F. A. Uzai, L. Whited, and R. M. Sauvajot. 2007. Anticoagulant exposure and notoedric mange in bobcats and mountain lions in urban southern California. Journal of Wildlife Management 71: 1874-1884.

Rudolph, S. G. 1978. Predation ecology of coexisting Great Horned and Barn Owls. The Wilson Bulletin 90: 134-137.

Rutz, C. 2008. The establishment of an urban bird population. Journal of Animal Ecology 77: 1008-1019. 
Sandor, A. D., and D. T. Ionesco. 2009. Diet of the Eagle Owl (Bubo bubo) in Brasov, Romania. North-Western Journal of Zoology 5: 170-178.

Sandor, A. D., and I. Moldovan. 2010. Heading to the city. Diet selection of urban breeding Desert Eagle Owls (Bubo ascalaphus) in Hurghada, Egypt. Journal of Arid Environments 74: 1146-1148.

Shin, D.-M., J.-C. Yoo, and Jeong D.-M. 2013. Spatial variation of Eurasian Eagle-Owl diets in wetland and nonwetland habitats in west-central Korea. Journal of Raptor Research 47: 400-409.

Stone, W. B., J. C. Okoniewski, and J. R. Stedelin. 1999. Poisoning of wildlife with anticoagulant rodenticides in New York. Journal of Wildlife Disease 35: 187-193.

Stone, W. B., J. C. Okoniewski, and J. R. Stedelin. 2003. Anticoagulant rodenticides and raptors: recent findings from New York, 1998-2001. Bulletin of Environmental Contamination and Toxicology 70: 34-40.
Thomas, P. J., P. Mineau, R. F. Shore, L. Champoux, P. A. Martin, L. K. Wilson, G. Fitzgerald, and J. E. Elliott. 2011. Second generation anticoagulant rodenticides in predatory birds: probabilistic characterisation of toxic liver concentrations and implications for predatory bird populations in Canada. Environmental International 37: 914 920.

Tosh, D. G., R. A. McDonald, S. Bearhop, N. R. Llewellyn, W. I. Montgomery, and R. F. Shore. 2012. Rodenticide exposure in wood mouse and house mouse populations on farms and potential secondary risk to predators. Ecotoxicology 21: 1325-1332.

Van Damme, L. M. 2005. Diet of the Great Horned Owl in the Creston Valley, British Columbia, 1998-2005. Wildlife Afield 1: 67-69.

Received 17 March 2014

Accepted 28 June 2014 